JURNAL KEBIDANAN

Vol 6, No 4, Oktober 2020 : 470-480

\title{
KONTRIBUSI EMPAT VARIABEL YANG BERPENGARUH DALAM PEMILIHAN STRATEGI COPING POST PARTUM DEPRESSION
}

\author{
Yesi Putri' ${ }^{1}$ Hedy Hardiana² ${ }^{2}$ Desi Aulia Umami ${ }^{3}$, Taufianie Rossita ${ }^{4}$ \\ 1,3,4Universitas Dehasen Bengkulu \\ 1email: yesiputri37@gmail.com \\ 2 STIKIM Jakarta. \\ 2email: hedy.hardiana@gmail.com \\ 3email: desiumami@gmail.com \\ 4email: taufianirossita255@gmail.com
}

\begin{abstract}
Background: Postpartum depression is the most common psychological disorder in postpartum mothers. The prevalence of postpairtum depression according to WHO was 30-200 per 1000 live births and the preliminary study found 31 out of 50 postpartum mothers have postpartum depression. To overcome postpartum depression required a good coping strategy of the mother.

Purpose: of this research is to know the direct and indirect influence and magnitude between family environment, husband role, self-concept, and health status to coping strategy of mother having postpartum depression at Puskesmas Kecamatan Jagakarsa South Jakarta.

Methods: The research method that used was quantitative using cross-sectional design with 80 respondents who had postpartum depression after screening. The analytical method used is the Structural Equation Model (SEM) using SmartPLS 2.0 and SPSS 20.

Results: The findings of this research are coping strategy influenced family environment $24.7 \%$, husband role $23.6 \%$, self-concept $28.3 \%$ and health status $17.9 \%$. The direct influence of coping strategies of mothers who experienced postpartum depression was $94.6 \%$ and indirect effect was $2.11 \%$. Therefore, total direct and indirect influences of coping strategy were $96.7 \%$.

Conclution: This research conclude that self-concept has greater influence than other variables because self-concept determines mother's self-confidence to do new responsibilities as mother. Husband should give attention, compassion, and motivation the mother in order to increase mother's confidence and more honest to husband.

Suggestion: This study recommends husbands to help their wives to increase self-confidence by providing attention, love and motivation to mothers so that postpartum mothers feel less alone and feel confident in carrying out their new roles. Then the mother must also be able to increase self-confidence to care for the baby, hold back emotions and be more open to her husband and family.
\end{abstract}

Keywords: Coping, environment, husband, Self Concept

\section{ABSTRAK}

Latar Belakang: Postpartum depression merupakan gangguan psikologi yang paling sering terjadi pada ibu postpartum. Prevalensi postpartum depression menurut WHO sebesar 30-200 per 1000 kelahiran hidup dan studi pendahuluan peneliti didapatkan 31 dari 50 ibu postpartum yang mengalami postpartum depression. Untuk mengatasi postpartum depression diperlukan strategi coping yang baik dari ibu.

Tujuan penelitian: mengetahui pengaruh langsung dan tidak langsung serta besarannya antara lingkungan keluarga, peran suami, self-concept, dan status kesehatan terhadap strategi coping ibu yang mengalami postpartum depression di Puskesmas Kecamatan Jagakarsa Jakarta Selatan.

Metode: Penelitian ini adalah kuantitatif yang menggunakan desain cross-sectional dengan responden sebanyak 80 ibu yang mengalami postpartum depression setelah dilakukan skrinning. Metode analisis yang digunakan adalah Structural Equation Model (SEM) mengunakan SmartPLS 2.0 dan SPSS 20.

Hasil: Hasil analisis SEM menggunakan SmartPLS ditemuan yaitu strategi coping dipengaruhi lingkungan keluarga sebesar $24,7 \%$, peran suami $23,6 \%$, self-concept $28,3 \%$ dan status kesehatan $17,9 \%$. Pengaruh langsung 
strategi coping ibu yang mengalami postpartum depression sebesar $94,6 \%$ dan pengaruh tidak langsung sebesar $2,11 \%$. Sehingga total pengaruh langsung dan tidak langsung strategi coping sebesar $96,7 \%$.

Kesimpulan: dari penelitian ini menunjukkan bahwa self-concept memiliki pengaruh dan peranan yang lebih besar dibanding variabel lainnya karena self-concept menentukan kepercayaan diri ibu untuk melakukan tanggung jawab baru sebagai seorang ibu. Suami harus memberikan perhatian, kasih sayang, dan memotivasi ibu supaya meningkatkan rasa percaya diri ibu dan lebih terbuka terhadap suami.

Saran : Penelitian ini merekomendasikan suami untuk membantu istrinya untuk meningkatkan kepercayaan diri dengan cara memberikan perhatian, kasih sayang dan motivasi untuk ibu supaya ibu postpartum merasa tidak sendiri dan merasa percaya diri untuk melakukan peran barunya. Kemudian ibu juga harus dapat meningkatkan kepercayaan diri untuk merawat bayi, menahan emosi dan lebih terbuka terhadap suami maupun keluarga.

Kata Kunci $\quad$ : Coping, lingkungan, suami, self concept

\section{PENDAHULUAN}

Kelahiran seorang bayi merupakan suatu peristiwa dan keadaan yang paling membahagiakan dan paling ditunggu dalam kehidupan perempuan. Kehadiran seorang bayi merupakan suatu bentuk penghargaan bagi perempuan, namun dapat pula sebaliknya, kelahiran seorang bayi dapat menimbulkan perasaan yang tertekan atas kelahiran seorang bayi. Bagi seorang perempuan menjadi ibu merupakan suatu keadaan yang akan membawa perubahan besar terhadap kehidupannya. Seorang wanita yang baru saja menjadi seorang ibu akan segera mempunyai beban dan tanggung jawab yang berat segera setelah kelahiran bayinya sebagai seorang ibu yang merawat dan menjaga bayinya. (Yustisia, 2013)

Pada masa nifas atau postpartum, seorang perempuan yang setelah melahirkan akan mengalami perubahan pada organ reproduksi. Selain itu seorang perempuan yang setelah melahirkan juga akan mengalami perubahan psikologi. ( Susilowati, 2013)

Selama masa kehamilan, persalinan dan postpartum seorang perempuan dalam proses penyesuaian menjadi ibu sangatlah rentan terhadap gangguan emosi. Seorang wanita setelah melahirkan dan menjadi seorang ibu dengan aktivitas baru dan tanggung jawab yang lebih berat perlu menyesuaian diri baik dari segi fisik maupun spikis dalam waktu beberapa minggu atau bulan pertama. Sebagian ibu postpartum berhasil dengan baik menyesuaikan diri pada masa postpartum, tetapi ada sebagian ibu postpartum lainnya yang tidak berhasil dalam menyesuaikan diri dan mengalami berbagai gejala gangguan psikologis. (Yustisia, 2013)

Postpartum depression adalah salah satu permasalahan gangguan psikologis yang sering terjadi pada ibu postpartum. Antara 13 dan $19 \%$ dari wanita melaporkan gejala peningkatan depresi pada tahun pertama setelah melahirkan. (O'Hara dan McCabe, 2013)

Postpartum depression meliputi gangguan mulai keparahan dari baby blues ke postpartum psikosis dengan timbulnya episode dalam waktu 4-6 minggu setelah lahir. (Thurgood, 2009) Penelitian sebelumnya telah mengemukakan bahwa sekitar 50 $80 \%$ dari wanita menderita baby blues setelah melahirkan, tapi perkiraan prevalensi gangguan postpartum depression secara substansial berbedabeda tergantung pada penilaian dan waktu skrining, ukuran sampel dan populasi karakteristik. Sebagian besar penelitian sebelumnya telah mengidentifikasi gejala depresi dengan wawancara atau laporan instrumen skrining depresi, seperti Edinburgh Postnatal Depression Scale (EPDS), bisa juga ditentukan berdasarkan diagnosa dokter. (Raisanen, 2016)

Menurut WHO diperkirakan angka kejadian atau prevalensi postpartum depression wanita yang mengalami depresi ringan sekitar 10 per 1000 kelahiran hidup dan postpartum depression sekitar 30 sampai 200 per 1000 kelahiran hidup di kategorikan sedang maupun berat. (WHO. 2012) Menurut Centers for Disease Control and Prevention (CDC) prevalensi postpartum depression sekitar $11.7 \%$ sampai $20.4 \%$ pada tahun 2004-2005. (Barclay, 2008) Di Indonesia sampai sekarang angka kejadian postpartum depression belum dapat dipastikan, karena belum terdapat lembaga penelitian terkait kasus postpartum depression. (Yustisia, 2013)

DKI Jakarta merupakan provinsi yang memiliki jumlah penduduk terpadat di Indonesia. Tetapi angka kejadian orang dengan gangguan jiwa dapat kita ketahuisekitar $7-8 \%$ atau $17,5-20$ juta dari 250 juta jiwa total orang yang menderita gangguan jiwa di Indonesia adalah perempuan, $7 \%$ atau 1,7 juta jiwa berasal dari perkotaan termasuk salah satunya adalah kota Jakarta dengan tingkat kepadatan penduduk yang cukup tinggi dan stessor 
yang beraneka macam. Angka orang dengan gangguan jiwa di DKI Jakarta sebesar $5,7 \%$ atau 568.284 jiwa orang dengan gangguan jiwa. (RIKESDAS, 2013)

Dengan angka kejadian postpartum depression belum diketahui maka peneliti melakukan strudi pendahuluan. Berdasarkan studi pendahuluan berupa skrining menggunakan EPDS (Edinburgh Postnatal Depression Scale) yang dilakukan pada ibu postpartum di Puskesma Kecamatan Jagakarsa pada tanggal 19-23 Desember 2016 menunjukkan bahwa 31 dari 50 ibu postpartum mengalami depresi dengan score $>10$.

Secara psikologis, seseorang yang mengalami depresi akan mencari jalan keluar untuk mengatasi perasaan-perasaan yang menekannya, seperti halnya pada ibu yang mengalami Postpartum Depression. (Janiwarty, 2013) Mereka berupaya untuk mengatasi apa yang bertentangan dengan hatinya dan kebutuhan hidup yang harus di penuhi. Dalam situasi-situasi tertentu yang menjadi stresor dapat mengakibatkan respon negatif baik secara fisik maupun psikologis. Tentunya mereka tidak akan membiarkan hal ini berlarut-larut. Mereka akan melakukan berbagai cara untuk mengatasi masalahmasalah tersebut. cara yang dilakukan dalam mengatasi masalah-masalah disebut dengan coping behavior. (Hadi, 2010)

Kemampuan setiap individu dalam memilih strategi coping dan menggunakannya untuk mengurangi tekanan adalah berbeda. Perbedaan juga terdapat dalam hal pemahaman mengenai bagaimana dan kapan harus memakai strategi coping yang diperlukan. (Soep, 2010) Faktor usia, jenis kelamin, status sosial ekonomi, kesadaran emosional, tingkat pendidikan, dan kesehatan fisik akan berpengaruh terhadap kecenderungan penggunaan strategi coping. (Kartono, 2010)

Tujuan penelitian ini untuk mengetahui pengaruh langsung dan tidak langsung serta besarannya antara pengaruh lingkungan keluarga, peran suami, self concept, dan status kesehatan ibu terhadap strategi coping ibu yang mengalami postpartum depression di Puskesmas Kecamatan Jagakarsa Jakarta Selatan tahun 2017.

\section{METODE}

Desain penelitian yang digunakan dalam penelitian ini adalah menggunakan metode pendekatan penelitian kuantitatif dengan desain cross-sectional. Penelitian ini dilakukan di Puskesmas Kecamatan Jagakarsa Jakarta Selatan pada Desember 2016 sampai Februari 2017. Jumlah sampel minimum /responden diambil langsung oleh peneliti melalui obyeknya sebanyak 80 orang responden. Untuk keperluan penelitian ini, responden ditentukan dengan melibatkan semua ibu postpartum yang mengalami depresi di Puskesmas Kecamatan Jagakarsa, Jakarta Selatan, dengan kriteria responden sebagai berikut: Kriteria inklusi adalah Ibu postpartum yang mengalami depresi yang melakukan kunjungan di Puskesmas Kecamatan Jagakarsa, Jakarta Selatan. Ibu postpartum yang bersedia dimengisi kuesioner. Sedangkan Kriteria eksklusi adalah Pada saat penelitian ibu postpartum yang memenuhi kriteria inklusi tetapi karena suatu hal berhalangan tidak dapat menjadi responden.

Jenis data yang dikumpulkan berupa data primer yakni data yang dikumpulkan melalui kuesioner yang dibagikan kepada responden dan diisi sendiri oleh responden. Kuesioner yang digunakan dalam penelitian ini adalah kuesioner yang dibuat untuk setiap indikator dari variabel dengan jenis parameter mendayagunakan skala pengukuran sematic differential.

Teknik distribusi kuesioner dilakukan secara tatap muka secara dengan bidan atau tenaga kesehatan Puskesmas Kecamatan Jagakarsa Jakarta Selatan, sekaligus melakukan wawancara singkat tentang data - data yang mungkin mendukung dan memperkuat proses pengambilan data dalam penelitian. Jenis data yang dikumpulkan berupa data sekunder yakni berupa hasil observasi dan dokumentasi di Puskesmas Kecamatan Jagakarsa Jakarta Selatan.

Diagram jalur Partial Least Square (SEM) berfungsi untuk menunjukkan pola hubungan antar variabel yang kita teliti. Dalam SEM pola hubungan antar variabel akan diisi dengan variabel yang diobservasi, variabel laten dan indicator. Didasarkan pola hubungan variabel, SEM dapat diuraikan menjadi dua sub-bagian yaitu: model pengukuran dan model structural. (Ghozali, 2011)

Langkah - langkah analisis SEM dengan Partial Least Square (PLS):

Merancang Model Struktural (inner model). Model ini menggambarkan hubungan kausaitas antara variabel laten (eksogen) dan variabel laten (endogen) berdasarkan landasan teori penelitian.Merancang model pengukuran (outer Model). Model ini mengukur bagaimana sebuah variabel laten diukur dengan indikator - indikatornya. Pengukuran ini dapat bersifat reflektif maupun formatif.Mengkonversi jalur kesosial persamaan. Konversi ini ada 2 yaitu: model persamaan pengukuran (inner model) dan persamaan structural (outer model).Estimasi : Koefisien jalur, loading dan weight. Evaluasi Goodness of Fit dari X2(Chi Square Statistic) dan probabilitas, model dikategorikan baik jika mempunyai chi square $=0$ berarti tidak ada 
perbedaan. Tingkat signifikan penerimaan yang direkomendasikan adalah apabila $p \geq 0,05$ (Zainal dan Tony, 2012), dalam penelitian ini melihat dari nilai $R$ Square. Evaluasi GOF dilakukan untuk mengukur seberapa baik nilai observasi dari model.Pengujian Hipotesis. Metode pengujian ini dilakukan dengan bootstrapping. Uji statistic yang digunakan adalah uji $\mathrm{T}$.

Teknik penyajian data dalam penelitian ini yaitu penyajian komposisi dan frekuensi dari sampel dan penyajian analisis SEM. Data yang disajikan pada asal hasil analisis adalah berupa tabel dan gambaran atau deskripsi mengenai sampel. Data penyajian analisis SEM dari pengolahan data output yang menggunakan bantuan SmartPLS 2.0, disajikan dalam diagram, tabel dan lain-lain.

\section{HASIL}

Hasil penelitian 80 Responden yang diteliti diambil dari semua ibu postpartum mengalami depresi yang sebelumnya dilakukan skrinning dengan mengisi kuisioner skala ukur Edinburgh Postnatal Depression Scale (EPDS) maka dapat dilihat distribusi responden berdasarkan umurnya paling banyak berumur< 25 tahun tahun, yaitu sebanyak 36 orang $(45,0 \%)$, kemudian dari segi pendidikan mayoritas berpendidikan SMA sebanyak 55 orang $(68,8 \%)$ dan yang terakhir dari segi pekerjaan mayoritas responden pekerjaannya adalah tidak bekerja sebanyak 45 orang $(56,3 \%)$.

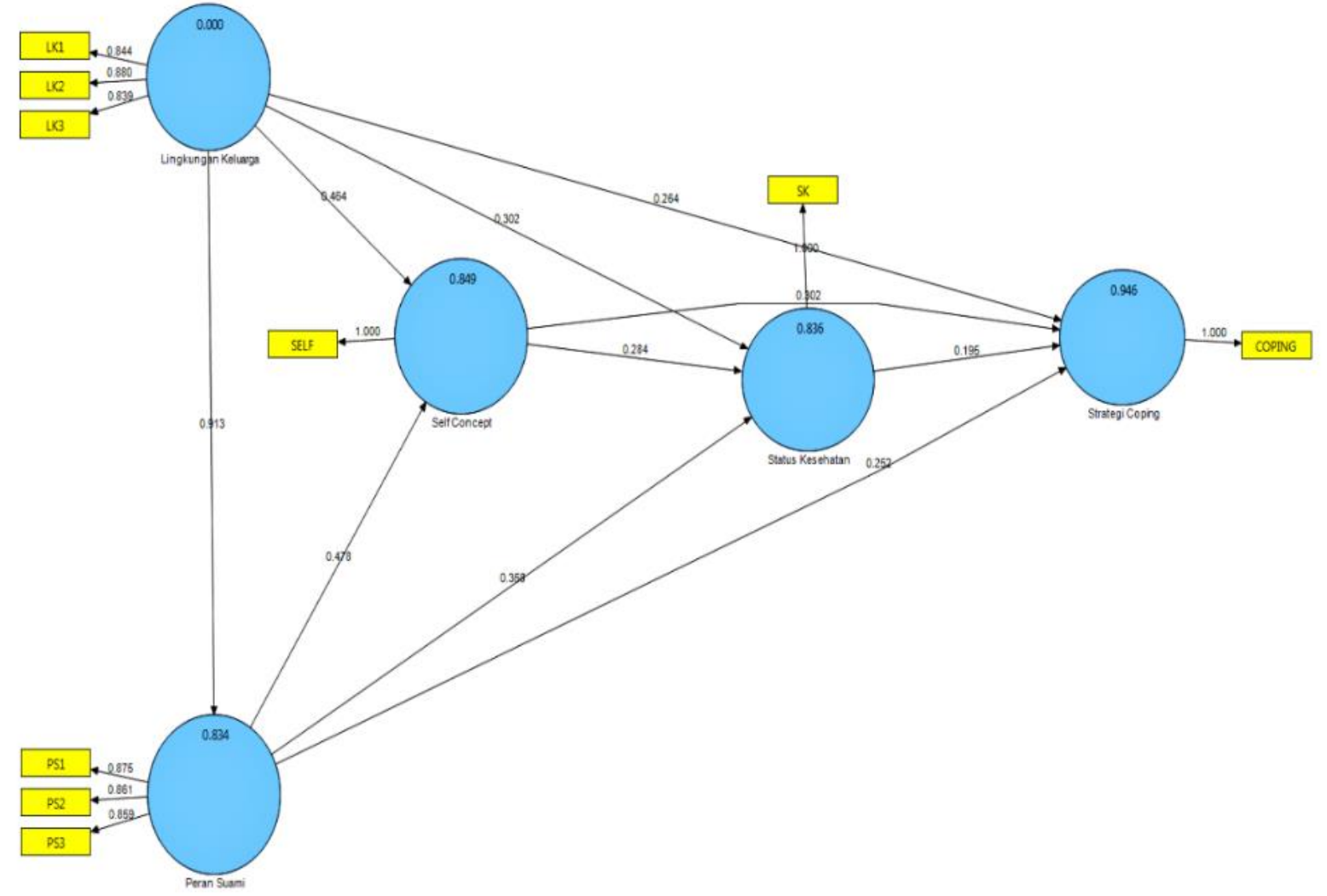

\section{Gambar 1}

Model Pengukuran atau Outer Model

Konstruk strategi coping mendapatkan mean sebesar 57,34 dan didapat median 57,50 nilai mode 58 dan nilai standar deviasinya mendapatkan nilai 7,535. Kemudian konstruk Lingkungan Keluarga mendapatkan mean sebesar 57,68 dan didapat median 58, nilai mode 58 dan nilai standar deviasinya. didapat median 56, nilai mode 60 dan nilai standar deviasinya mendapatkan nilai 7,675. Konstruk Self Concept dengan indikator citra diri, harga diri dan ideal diri mendapatkan mean sebesar 55,98 dan didapat median 57 , nilai mode 58 dan nilai standar deviasinya mendapatkan nilai 8,732. Sedangkan konstruk Status Kesehatan mendapatkan mean sebesar 55,94 dan didapat median 57 nilai mode 60 dan nilai standar deviasinya mendapatkan nilai 9,228.

Uji chi square dilakukan untuk melihat variasi total jawaban responden per variabel terhadap karakteristik penelitian. Hasil uji Chi Square bertujuan untuk melihat hubungan distribusi dari karakteristik individu (Umur, pendidikan, dan pekerjaan) dan variabel strategi coping, lingkungan 
keluarga, peran suami, self concept, dan status kesehatan.

Variabel strategi coping, lingkungan keluarga, peran suami, self concept, dan status kesehatan didapatkan hasil karakteristik umur, pendidikan dan pekerjaan tidak berhubungan dengan Strategi Coping karena $p$-valuenya $>0,05$ dengan kata lain tidak ada hubungan yang signifikan antara

Table 1

Evaluasi Avarage Variance Extracted

\begin{tabular}{llll}
\hline \multicolumn{1}{c}{ Variabel } & AVE & $\begin{array}{c}\text { Akar } \\
\text { AVE }\end{array}$ & $\begin{array}{c}\text { Kriteria } \\
\text { uji }>\mathbf{0 , 5}\end{array}$ \\
\hline Lingkungan & 0,729 & 0,854 & Valid \\
Keluarga & 0,748 & 0,865 & Valid \\
Peran Suami & 1 & 1 & Valid \\
Self Concept & 1 & 1 & Valid \\
Status Kesehatan & 1 & 1 & Valid \\
Strategi Coping & 1 & 1
\end{tabular}

Sumber : Pengolahan menggunakan SmartPLS 2017
Tabel 2

Evaluasi Nilai $R$ square

\begin{tabular}{lc}
\hline \multicolumn{1}{c}{ Variabel } & $\boldsymbol{R}$ Square \\
\hline Lingkungan Keluarga & \\
Peran Suami & 0,833805 \\
Self Concept & 0,848825 \\
Status Kesehatan & 0,836143 \\
Strategi Coping & 0,946041 \\
\hline Sumber : Pengolahan & menggunakan SmartPLS \\
2017 &
\end{tabular}

Strategi Coping dengan karakteristik responden atau tidak ada variasi terhadap jawaban responden.

Evaluasi outer model yang dapat dilihat pada gambar 1 bahwa indikator dapat dilakukan pengujian discriminat validity dan nilai loading factor. Pada hasil penelitian ini didapatkan bahwa nilai tertinggi tertinggi yaitu pengaruh antara lingkungan keluarga ke peran suami sebesar 0,913 serta nilai terendah yaitu pengaruh antara status kesehatan ke strategi coping sebesar 0,195.

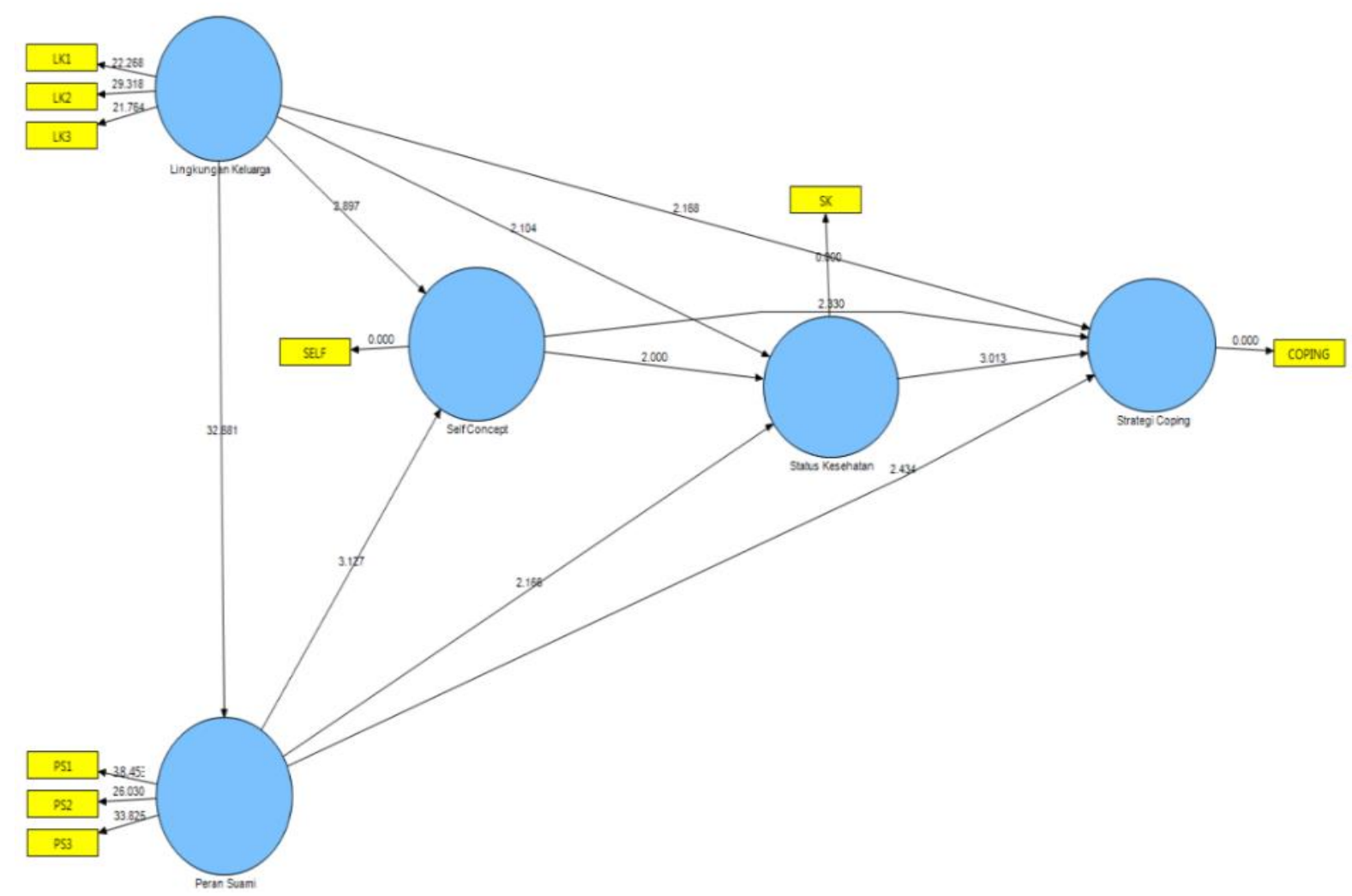

Gambar 2.

Inner Model (Uji T Statistik)

Pengukuran dengan membandingkan nilai square root of average variance extracted (AVE) setiap konstruk dengan korelasi antara konstruk dengan konstruk lain model penelitian ini. Evaluasi
AVE (average variance extracted) pada tabel 1 diatas kontruk lingkungan keluarga sebesar 0,729, peran suami sebesar 0,74 , self concept sebesar 1,0 , status kesehatan sebesar 1,0 dan strategi coping 
sebesar 1,0 dinyatakan valid karena nilai AVE di atas 0,5 dengan demikian dapat disimpulkan bahwa evaluasi pengukuran model memilki discriminat validity yang baik.

Evaluasi Inner Model berdasarkan gambar 2 dihalaman sebelumnya, didapatkan hasil semua jalur sudah memenuhi angka signifikan pada $\mathrm{Cl} 95 \%>$ $(1,96)$. Hal ini menjadi persyaratan pada evaluasi dengan loading factor yaitu dilakukan untuk menilai signifikansi konstruk laten dengan kosntruknya, dengan membandingkan nilai T-statistik masingmasing konstruk laten dengan nilai $a=5 \%(0,05)$. Dari gambar 2 terlihat bahwa nilai loading factor tertinggi yaitu pengaruh antara lingkungan keluarga ke peran suami sebesar 32,681 serta nilai terendah yaitu pengaruh antara self concept ke status kesehatan sebesar 2,000. Selanjutnya dilakukan uji inner model, pengujian terhadap model struktural dilakukan dengan $R$ square yang merupakan uji goodness fit model.

Nilai $R$ square adalah koefisien determinasi pada konstruk endogen. Nilai $R$ square sebesar 0,67 (kuat), sebesar 0,33 (sedang) dan sebesar 0,19 (lemah). Tabel 2 dihalaman berikutnya menjelaskan sumbangan dari variabel yang mempengaruhi variabel yang ada di tabel $R$-Square, nilai $R$-Square variabel peran suami sebesar 0,833805 . Artinya variabel lingkungan Keluarga mempengaruhi peran suami sebesar $83,38 \%$, sedangkan $16,62 \%$ dipengaruhi oleh faktor-faktor lain.
Kemudian nilai $R$-Square variabel self concept sebesar 0,848825. Artinya variabel lingkungan keluarga dan peran suami mempengaruhi self concept sebesar $84,88 \%$, sedangkan 15,12\% dipengaruhi oleh faktor-faktor lain. Lalu nilai $R$ Square variabel status kesehatan sebesar 0,836143 . Artinya variabel lingkungan keluarga, peran suami, dan self concept mempengaruhi status kesehatan concept mempengaruhi status kesehatan sebesar $883,61 \%$, sedangkan $16,39 \%$ dipengaruhi oleh faktor-faktor lain. Sedangkan nilai $R$-Square variabel strategi coping sebesar 0,946041. Artinya variabel lingkungan keluarga, peran suami, self concept, dan status kesehatan mempengaruhi strategi coping sebesar $94,60 \%$, sedangkan $5,4 \%$ dipengaruhi oleh faktor-faktor lain.

Semua variabel memiliki nilai $T$-statistik lebih besar dari 1,96 yaitu menunjukkan bahwa lingkungan keluarga berpengaruh terhadap peran suami dengan nilai $T$-statistik sebesar 32,681>1,96. Lingkungan keluarga berpengaruh terhadap self concept dengan nilai $T$-statistik sebesar 2,897>1,96. Lingkungan keluarga berpengaruh terhadap status kesehatan dengan nilai T-statistik sebesar $2,104>1,96$. Lingkungan keluarga berpengaruh terhadap strategi coping dengan nilai T-statistik sebesar 2,167>1,96. Peran suami berpengaruh terhadap self concept dengan nilai T-statistik sebesar $3,126>1,96$. Peran suami berpengaruh terhadap status kesehatan dengan nilai T-statistik sebesar 2,166>1,96.

Tabel 3

Presentase Pengaruh Antar Variabel Terhadap Strategi Coping pada Model

\begin{tabular}{lccccccc}
\hline \multicolumn{1}{c}{ Variabel } & $\begin{array}{c}\text { LV } \\
\text { Correlation }\end{array}$ & $\begin{array}{c}\text { Direct } \\
\text { Path }\end{array}$ & $\begin{array}{c}\text { Inderect } \\
\text { Path }\end{array}$ & Total & $\begin{array}{c}\text { Direct } \\
(\%)\end{array}$ & $\begin{array}{c}\text { Inderect } \\
(\%)\end{array}$ & $\begin{array}{c}\text { Total } \\
(\%)\end{array}$ \\
\hline Lingkungan & 0,938 & 0,263 & 5,424 & 5,688 & 24,74 & 1,451 & 26,19 \\
Keluarga & 0,938 & 0,251 & 2,391 & 2,643 & 23,64 & 0,657 & 24,296 \\
Peran Suami & 0,937 & 0,301 & 0,807 & 1,108 & 28,29 & 0,0016 & 28,288 \\
Self concept & 0,918 & 0,195 & - & 0,195 & 17,94 & 0,000 & 17,940 \\
Status Kesehatan & & Total & & & $94,6 \%$ & $2,11 \%$ & $96,7 \%$ \\
\hline
\end{tabular}

Sumber : Pengolahan menggunakan SmartPLS 2017

Tabel 3 menyatakan bahwa lingkungan keluarga berpengaruh secara langsung dan tidak langsung terhadap strategi coping. Hasil uji koefisien parameter antara lingkungan keluarga terhadap strategi coping menunjukkan terdapat pengaruh langsung sebesar 24,74\%. Peran suami berpengaruh secara langsung terhadap strategi coping. Hasil uji koefisien parameter antara peran suami terhadap strategi coping menunjukkan terdapat pengaruh langsung sebesar $23,64 \%$.Self concept berpengaruh secara langsung dan tidak langsung terhadap strategi coping. Hasil uji koefisien parameter antara Self concept terhadap strategi coping menunjukkan terdapat pengaruh langsung sebesar $28,29 \%$. Sedangkan, status kesehatan berpengaruh secara langsung terhadap strategi coping. Hasil uji koefisien parameter antara Status kesehatan terhadap strategi coping menunjukkan terdapat pengaruh langsung sebesar $17,94 \%$. 
Cara perhitungan pengaruh langsung lingkungan keluarga terhadap strategi coping adalah dengan cara mengalikan koefesien jalur (path) dari lingkungan keluarga terhadap strategi coping dengan laten variabelnya, hal ini yang juga berlaku untuk perhitungan koefisien jalur variabel lainnya. Hasil pengaruh langsungnya adalah:

Pengaruh Langsung Lingkungan Keluarga terhadap Strategi Coping

Direct Path (lingkungan keluarga $\rightarrow$ Strategi

Coping) $x$ LV

Correlation(lingkungan $\quad$ keluarga $\rightarrow$ Strategi

Coping)

$=(0,263694) \times(0,938178) \times 100 \%$

$=0,24739191 \times 100 \%$

$=24,7 \%$

Pengaruh Langsung Peran Suami terhadap Strategi Coping

Direct Path (peran suami $\rightarrow$ Strategi Coping) $x$

$L V$ Correlation (peran suami $\rightarrow$ Strategi Coping)

$=(0,251867) \times(0,938540) \times 100 \%$

$=0,23638721 \times 100 \%$

$=23,6 \%$

Pengaruh Langsung Self Concept terhadap Strategi Coping

Direct Path (self concept $\rightarrow$ Strategi Coping) $x$

$L V$ Correlation (self concept $\rightarrow$ Strategi Coping)

$=(0,301584) \times(0,937929) \times 100 \%$

$=0,28286438 \times 100 \%$

$=28,3 \%$

Pengaruh Langsung Status Kesehatan terhadap Strategi Coping

Direct Path (peran suami $\rightarrow$ Strategi Coping) $x$

LV Correlation (peran suami $\rightarrow$ Strategi Coping)

$=(0,195384) \times(0,918171) \times 100 \%$

$=0,17939592 \times 100 \%$

$=17,9 \%$

Sehingga nilai dari masing-masing pengaruh langsung variabel laten independent tersebut apabila secara bersama-sama menunjukkan kesesuaian dengan nilai $R$ square atau dengan kata lain hal ini menyatakan bahwa variabel lingkungan keluarga, peran suami, self concept dan status kesehatan mampu menjelaskan variabel strategi coping sebesar $(24,74 \%+27,7 \%+23,64 \%+28,29 \%)=$ $94,6 \%$.

Dari hasi perhitungan Nilai Q-Square dengan rumus didapat nilai Q-Square sebesar 99,7\% keragaman data, dan dapat mengkaji fenomena dalam penelitian dan galat model sebesar 0,3\% adalah komponen lain yang tidak ada dalam penelitian ini.

Dari hasil perhitungan ini hipotesis yang diajukan oleh peneliti dalam penelitian Pengaruh lingkungan keluarga, peran suami, self concept, dan status kesehatan terhadap strategi coping diterima.

\section{PEMBAHASAN \\ Pengaruh Antar Variabel Lingkungan Keluarga Terhadap Strategi Coping Ibu yang mengalami Postpartum Depression}

Hasil pengujian lingkungan keluarga terhadap strategi coping didapat dengan nilai T-statistik sebesar 2,167 >1,96 dan hasil penelitian ini ada pengaruh langsung antara lingkungan keluarga terhadap strategi coping sebesar 0,263. Sehingga parameter lingkungan keluarga terhadap strategi coping dikatakan signifikan. Indikator yang digunakan pada lingkungan keluarga yaitu kondisi rumah, keharmonisan antar anggota keluarga, dan intensitas komunikasi keluarga.

Hasil penelitian ini sejalan dengan penelitian yang berjudul hubungan antara lingkungan keluarga dengan coping kecemasan ibu dalam menghadapi persalinan di RSUD M Yunus Bengkulu. Diperoleh hasil bahwa ada hubungan yang signifikan antara lingkungan keluargadengan coping kecemasan ibu dalam menghadapi persalinan ( $p$ value $=0,000$ ). Maka dapat disimpulkan bahwa semakin baik lingkungan keluarga, semakin bagus coping yang ibu lakukan. (Andriyani, 2015)

Menurut Peneliti lingkungan keluarga mempengaruhi strategi coping ibu yang mengalami postpartum depression sebabkan lingkungan keluarga merupakan lingkungan pertama seseorang dalam berinteraksi. Dimana lingkungan yang nyaman, bersih, dan hubungan antar anggota keluarga baik serta intensitas komunikasi keluarga juga baik dan terjaga akan memberikan ketenangan ibu upaya untuk strategi coping dalam mengatasi postpartum depression yang ibu alami.

\section{Pengaruh Antar Variabel Peran Suami Terhadap Strategi Coping Ibu yang mengalami Postpartum Depression}

Hasil pengujian peran suami terhadap strategi coping didapat dengan nilai T-statistik sebesar 2,434 >1,96 dan hasil penelitian ini ada pengaruh langsung antara peran suami terhadap strategi coping sebesar 0,251 . Sehingga parameter peran suami terhadap strategi coping dikatakan berpengaruh positif dan signifikan. Indikator yang digunakan dalam peran suami yaitu emosional, instrumental dan informasi.

Hasil penelitian ini sejalan dengan penelitian yang berjudul Hubungan Dukungan Suami Dengan Kejadian Postpartum Blues Pada Ibu Primipara Di Ruang Bugenvile RSUD Tugurejo Semarang. Hasil penelitian menunjukkan bahwa hasil uji chi square 
membuktikan adanya hubungan dukungan Suami dengan kejadian Postpartum Blues pada lbu primipara di ruang Bugenvile RSUD Tugurejo Semarang dengan $p$-value $=0,033$. Maka diperlukan dukungan suami yang lebih kepada istri melahirkan untuk mencegah gejala Postpartum Blues. Dari hasil penelitian di dapatkan ada hubungan antara dukungan suami dengan kejadian Postpartum Blues pada ibu primipara di ruang bugenvile RSUD Tugurejo Semarang. (Fatimah, 2013)

Menurut peneliti peran suami mempengaruhi strategi coping disebabkan karena suami merupakan orang pertama dan terdekat seoorang istri. Peran suami yaitu Pertama perhatian emosional yang diekspresikan melalui rasa suka, cinta atau empati, kedua, bantuan instrumental seperti penyediaan jasa atau barang. Ketiga memberikan informasi tentang situasi yang menekan. Peran suami sangat berpengaruh terhadap strategi coping ibu yang mengalami postpartum depression karena dengan perhatian, bantuan, pengertian suami baik dalam emosional, instrumental maupun informasi. Istri akan merasa nyaman dan aman jika ada dukungan dari seseorang yang paling dekat dikehidupannya. Suami yang selalu mendampingi istri dan membantu pekerjaan istri akan meringankan stress (depresi) yang di alami ibu postpartum tersebut.

\section{Pengaruh Antar Variabel Self Concept Terhadap Strategi coping lbu yang Mengalami Postpartum Depression}

Hasil pengujian self concept terhadap strategi coping didapat dengan nilai T-statistik sebesar $0,301>1,96$ dan hasil penelitian ini ada pengaruh langsung antara peran suami terhadap strategi coping sebesar 2,329. Sehingga parameter self concept terhadap strategi coping dikatakan berpengaruh positif dan signifikan.

Hasil penelitian sejalan dengan penelitiandengan judul hubungan antara self concept dengan strategi coping pada mahasiswa, didapatkan hubungan antara self concept dengan strategi coping menunjukkan angka korelasi $r=0,535$ dengan taraf signifikansi $p=0,000 \quad(p<0,01)$. Jadi, hipotesis mengenai adanya hubungan yang positif antara self concept dengan strategi coping, dapat diterima. Untuk variabel Self concept, subjek yang termasuk dalam kategori yang Sangat Positif sebesar 35.71\%, untuk kategori Positif sebesar $64.29 \%$, serta tidak terdapat subjek yang termasuk kategori Negatif dan Sangat Negatif. Sedangkan, pada variabel Strategi Coping, subjek yang termasuk kategori Sangat Baik sebesar $83.33 \%$, untuk kategori Baik sebesar $16.67 \%$, serta tidak terdapat subjek yang termasuk kategori Buruk dan Sangat Buruk. Oleh karena itu, dapat disimpulkan bahwa self concept sangat berhubungan erat dengan strategi coping. (Zuama, 2010)

Menurut peneliti self-concept mempengaruhi strategi coping disebabkan karena self-concept merupakan gambaran diri seseorang, pengetahuan dan gagasan seseorang tentang dirinya serta sikap terhadap diri dan perilakunya, apakah memiliki konsep diri positif atau negatif. Semakin positif dan baik konsep diri seorang ibu postpartum semakin baik pula strategi coping yang dilakukan ibu dalam mengatasi postpartum depression yang ibu alami. Sebaliknya, ibu yang memiliki konsep diri negatif, ibu akan memiliki strategi coping yang buruk dalam mengatasi postpartum depression yang ibu alami.

\section{Pengaruh Antar Variabel Status Kesehatan Terhadap Strategi Coping lbu yang mengalami Postpartum Depression}

Hasil pengujian status kesehatan terhadap strategi coping didapat dengan nilai $T$ statistik sebesar 3,012>1,96 dan hasil penelitian ini ada pengaruh langsung antara status kesehatan terhadap strategi coping sebesar 0,195. Sehingga parameter status kesehatan terhadap strategi coping dikatakan berpengaruh positif dan signifikan Penelitian dengan judul Hubungan antara Strategi Koping dengan Kualitas Hidup pada Penderita Skizofrenia Remisi Simptom. Analisis data dilakukan dengan menggunakan statistik korelasi product moment Pearson. Diperoleh nilai korelasi sebesar 0.757 dengan taraf signifikansi 0.001. Hasil perhitungan menunjukkan ada korelasi positif antara strategi koping dengan kualitas hidup penderita skizofreniar emisi symptom. (Rubbyana, 2012)

Menurut peneliti status kesehatan mempengaruhi strategi coping disebabkan karena status kesehatan merupakan hal yang paling penting dan mempengaruhi aktivitas yang akan dilakukan oleh ibu postpartum. Semakin baik status kesehatan ibu postpartum semakin baik pula strategi coping yang dilakukan oleh ibu postpartum dalam mengatasi postpartum depression yang dialami.

\section{Pengaruh Antar Variabel Lingkungan Keluarga Terhadap Peran Suami Ibu yang mengalami Postpartum}

Hasil pengujian lingkungan keluarga terhadap peran suami didapat dengan nilai $T$ statistik sebesar 32,681> 1,96 dan hasil penelitian ini ada pengaruh langsung antara lingkungan keluarga terhadap peran suami sebesar 0,913. Sehingga parameter lingkungan keluarga terhadap peran suami dikatakan berpengaruh positif dan signifikan. 
Penelitian ini sejalan dengan penelitian yang berjudul hubungan keharmonisan keluarga dengan peran suami dalam mengambil keputusan tindakan sectio caesarea pada ibu partus lama Tahun 2011. Hasil penelitian bahwa ada hubungan antara keharmonisan keluarga dengan peran suami, semakin harmonis keluarga maka semakin bagus peran suami dalam mengambil keputusan. (Hartati, 2011)

Menurut peneliti lingkungan keluarga mempengaruhi peran suami karena untuk melakukan peran sebagai suami, dibutuhkan hubungan antar anggota keluarga yang baik. Jika didalam suatu keluarga terdapat masalah misalnya antara mertua dan suami dalam mengambil keputusan tertinggi masih di lakukan oleh mertua makan suami merasi tidak memiliki tanggu jawab sepenuhnya terhadap ibu postpartum maka suami tidak akan melakukan peran suami engan sepenuhnya.

\section{Pengaruh Antar Variabel Lingkungan Keluarga Terhadap Self Concept Ibu yang mengalami Postpartum Depression}

Hasil pengujian lingkungan keluarga terhadap self concept didapat dengan nilai T statistik sebesar 2,897 > 1,96 dan hasil penelitian ini ada pengaruh langsung antara lingkungan keluarga terhadap self concept sebesar 0,463. Sehingga parameter lingkungan keluarga terhadap self concept dikatakan berpengaruh positif dan signifikan.

Penelitian ini sejalan dengan penelitian yang berjudul Pengaruh Konsep Diri Dan Lingkungan Keluarga Terhadap Minat Belajar Siswa Program Studi TeknikKendaraan Ringan Di Smk Piri 1 Yogyakarta Tahun 2013, menyatakan adapengaruh konsep diri dan lingkungan keluarga terhadap minat belajar siswa programstudi Teknik Kendaraan Ringan di SMK Piri 1 Yogyakarta. Didapatkan hasil lingkungan keluarga mempunyai pengaruh terhadap konsep diri. (Prihantoro, 2013)

Menurut peneliti lingkungan keluarga merupakan lingkungan social kecil yang akan membentuk konsep diri seseorang. semakin baik lingkungan keluarga akan membentuk konsep diri positif atau baik. Sebaliknya, lingkungan keluarga yang buruk akan membentuk konsep diri yang negatif atau buruk pula.

\section{Pengaruh Antar Variabel Lingkungan Keluarga Terhadap Status Kesehatan Ibu yang mengalami Postpartum Depression}

Hasil pengujian lingkungan keluarga terhadap status kesehatan didapat dengan nilai $\mathrm{T}$ statistik sebesar 2,104 > 1,96 dan hasil penelitian ini ada pengaruh langsung antara lingkungan keluarga terhadap status kesehatan sebesar 0,302. Sehingga parameter lingkungan keluarga terhadap status kesehatan dikatakan berpengaruh positif dan signifikan.

Hasil penelitian ini sejalan dengan penelitian yang berjudul hubungan antara lingkungan keluarga dengan diare pada anak di RSUD M Yunus Bengkulu. Diperoleh hasil bahwa ada hubungan yang signifikan antara lingkungan keluargadengan diare pada anak ( $p$ value $=0,004$ ). Maka dapat disimpulkan bahwa lingkungan keluarga yang tidak bersih akan menyebabkan diare pada anak. (Adisasmito, 2013)

Menurut peneliti lingkungan keluarga merupakan lingkungan tempat tinggal ibu postpartum untuk istirahat dan berbagai aktivitas lainnya. Lingkungan tempat tinggal yang bersih, nyaman dan tenang akan meningkatkan status kesehatan. Sebaliknya, lingkungan keluarga yang kotor, tidak nyaman dan penuh kegaduhan akan menurunkan status kesehatan ibu postpartum. Apalagi ibu postpartum memerlukan lingkungan yang baik untuk memulihkan fisik maupun spikis setelah melahirkan.

\section{Pengaruh Antar Variabel Peran Suami Terhadap Self Concept lbu yang mengalami Postpartum Depression}

Hasil pengujian peran suami terhadap self concept didapat dengan nilai $T$-statistik sebesar $3,126>1,96$ dan hasil penelitian ini ada pengaruh langsung antara peran suami terhadap self concept sebesar 0,478 . Sehingga parameter peran suami terhadap self concept dikatakan berpengaruh positif dan signifikan.

Hasil penelitian ini sejalan dengan penelitian yang berjudul hubungan antara peran suami dengan meningkatnya konsep diri positif ibu postpartum bluse di wilayah puskesmas Nusa Indah Bengkulu. Diperoleh hasil bahwa ada hubungan yang signifikan antara Peran suami dengan meningkatnya konsep diri positif ibu postpartum bluse ( $p$ value $=0,004$ ). Maka dapat disimpulkan bahwa peran suami yang baik akan meningkatkan konsep diri yang baik untuk ibu postpartum bluse. (Ayu, 2013)

Menurut peneliti peran suami merupakan sesuatu yang diharapkan oleh seorang istri. Suami yang memperlakukan istri dengan baik, memberikan perhatian, kasih sayang akan meningkatkan rasa percaya diri dan merasa berarti dalam suatu rumah tangga. Suami yang baik merupakan suami yang sangat di harapkan oleh semua istri untuk motivasi dalam melakukan tugas sebagai ibu dan seorang 
istri. Semakin baik peran suami semakin baik dan positif pula konsep diri ibu postpartum.

\section{Pengaruh Antar Variabel Peran Suami Terhadap Status Kesehatan lbu yang mengalami Postpartum Depression}

Hasil pengujian peran suami terhadap status kesehatan didapat dengan nilai $T$-statistik sebesar 2,166> 1,96 dan hasil penelitian ini ada pengaruh langsung antara peran suami terhadap status kesehatan sebesar 0,357. Sehingga parameter peran suami terhadap status kesehatan dikatakan berpengaruh positif dan signifikan.

Penelitian ini sejalan dengan penelitian hubungan antara peran suami siaga dengan frekuensi kunjungan antenatal care (anc) pada ibu hamil trimester III di kelurahan pojok sari kecamatan ambarawa kabupaten semarang. Didapatkan hasil peran suami paling banyak pada kategori tidak siaga $51,4 \%$ dan siaga $48,5 \%$ dan frekuensi kunjungan ANC pada kategori cukup 56,8\% dan kategori kurang $43,2 \%$. Hasil penelitian menunjukkan ada hubungan yang bermakna antara peran suami siaga dengan frekuensi kunjungan ANC ( $p=0,029)$. (Puspita, 2015)

Menurut peneliti semakin baik peran suami semakin baik pula status kesehatan ibu karena peran suami merupakan sesuatu bentuk dukungan fisik maupun psikis baik berupa emosional, instrumetal dan informasi. Suami yang perhatian dan penuh kasih sayang akan membuat ibu merasa tidak sendiri dan dihargai sehingga ibu postpartum semakan untuk menjalankan prose pemulihan tubuh setelah melahirkan.

\section{Pengaruh Antar Variabel Lingkungan Self Concept terhadap Status Kesehatan lbu yang mengalami Postpartum Depression}

Self concept dibagi menjadi self concept positif dan self concept negatif. Individu dengan self concept positif akan mengembangkan sikap-sikap seperti kepercayaan diri, harga diri dan kemampuan untuk melihat dirinya secara realistis. Kemudian individu dapat menilai hubungan dengan orang lain secara tepat dan akan menumbuhkan penyesuaian sosial yang baik. Sebaliknya, self concept negatif akan mengambarkan perasaan tidak mampu dan rendah diri. Individu akan merasa ragu dan kurang percaya diri.

Penelitian ini sejalan dengan penelitian yang berjudul pengaruh konsep diri terhadap status kesehatan ibu postpartum di wilayah puskesmas napal. Diperoleh hasil bahwa ada hubungan yang signifikan antara konsep diri terhadap status kesehatan ibu postpartum ( $p$ value $=0,003$ ). Maka dapat disimpulkan bahwa konsep diri yang baik akan berpengaruh terhadap status kesehatan ibu postpartum. (Sari, 2015)

Hasil pengujian peran suami terhadap status kesehatan didapat dengan nilai $\mathrm{T}$ statistik sebesar 1,999 > 1,96 dan hasil penelitian ini ada pengaruh langsung antara peran suami terhadap status kesehatan sebesar 0,284 . Sehingga parameter self concept terhadap status kesehatan dikatakan berpengaruh positif dan signifikan.

\section{KESIMPULAN}

Dengan demikian, dari temuan tersebut dapat ditarik kesimpulan bahwa self concept yang sangat mempengaruhi strategi coping ibu yang mengalami postpartum depression di Puskesmas Kecamatan Jagakarsa Jakarta SelatanTahun 2017. Dikarena self concept atau konsep diri merupakan pandangan atau gambaran ibu postpartum terhadap dirinya sendiri yang berupa kemampuan dan kepercayaan diri ibu postpartum dalam memilih, menentukan dan melakukan strategi coping untuk mengatasi postpartum depression yang dialami oleh ibu.

Dilapangan ibu yang mengalami postpartum depression mempunyai semangat dan kemampuan untuk mengatasi depresi yang ialami dengan berbagai cara, karena mereka mempunyai kepercayaan yang tinggi dan semangat yang tinggi untuk merawat bayinya dan menjaga bayinya tetap sehat dan tumbuh kembang dengan baik. Dari itulah ibu postpartum depression tidak mau berlarut dengan masalah yang dihadapinya dan terus berusaha untuk mengatasi deprsi tersebut. Karena mereka tidak mau dengan kesulitan yang mereka alami bisa mengganggu pertumbuhan dan perkembangan anaknya.

Jadi dari hasil statistic dapat disimpulkan semakin positif konsep diri ibu postpartum semakin baik pula strategi coping yang dilakukan oleh ibu postpartum untuk mengatasi depresi tersebut.

\section{SARAN}

Penelitian ini merekomendasikan suami untuk membantu istrinya untuk meningkatkan kepercayaan diri dengan cara memberikan perhatian, kasih sayang dan motivasi untuk ibu supaya ibu postpartum merasa tidak sendiri dan merasa percaya diri untuk melakukan peran barunya. Kemudian ibu juga harus dapat meningkatkan kepercayaan diri untuk merawat bayi, menahan emosi dan lebih terbuka terhadap suami maupun keluarga.

\section{DAFTAR PUSTAKA}

Adisasmito. (2013). Hubungan Antara Lingkungan Keluarga Dengan Diare Pada Anak Di RSUD 
M Yunus Bengkulu. Jurnal Dosen Universitas Bengkulu No.14 Vol.3

Andriyani, Anisa. (2015). Hubungan Antara Lingkungan Keluarga dengan Coping Kecemasan lbu dalam Menghadapi Persalinan di RSUD M.Yunus Bengkulu. Jurnal Kebidanan. Dosen Poltekkes Kemenkes Bengkulu Jurusan Kebidanan No:19 Vol. 2

Ayu, Ida. (2013). Hubungan Antara Peran Suami dengan Konsep Diri Positif Ibu Postpartum Blues. Jurnal Dosen Universitas Bengkulu No. 19 Vol.3

Balitbang Kemenkes RI. (2013). Riset Kesehatan Dasar; RISKESDAS. Jakarta: Balitbang Kemenkes Rl;

Barclay, Laurie. (2008). Medscape Medical News: Prevalence of Self-Reported Postpartum Depression Symptoms Ranges From 11.7\% to $20.4 \%, 57(14) ; 361-366$;

Fatimah. (2013). Hubungan Dukungan Suami Dengan Kejadian Postpartum Blues Pada lbu Primipara Di Ruang Bugenvile RSUD Tugurejo Semarang. Jurnal IImu Keperawatan Universitas Pesantren Tinggi Darul Ulum Jombang No.1 Vol.1

Ghozali, Imam. (2011). Structural Equation Modeling Metode Alternative dengan Partial Least Square. Badan Penerbit Universitas Diponegoro: Semarang;

Hadi, P. (2010). Depresi dan Solusinya. Tugu: Yogyakarta;

Hartati, Tri. (2011). Hubungan Keharmonisan Keluarga Dengan Peran Suami dalam Mengambil Keputusan Tindakan Sectio Caesarea Pada Ibu Partus Lama Tahun 2011. Jurnal Dosen Universitas Muhammadiyah Bengkulu No.03 Vol.2

Janiwarty, B. H. Z. Pieter. (2013). Pendidikan psikologi untuk bidan-suatu teori dan terapannya. Rapha Publishing: Yogyakarta;

Kartono, D. (2010). Psikologi Wanita Patologi Sosial 3. Raja Grafindo Persada: Jakarta;

O'Hara dan McCabe. (2013). Postpartum Depression:Current Status and Future Directions. http://dx.doi:101146/annurevclinpsy-050212-185612;

Prihantoro, Nugroho. (2013). Pengaruh Konsep Diri Dan Lingkungan Keluarga Terhadap Minat
Belajar Siswa Program Studi Teknik Kendaraan Ringan Di Smk Piri 1 Yogyakarta Tahun 2013. Jurnal Dosen Universitas Negeri Yogyakarta No.14 Vol.2

Puspita, Mike Ahyu. (2015). Hubungan Antara Peran Suami Siaga Dengan Frekuensi Kunjungan Antenatal Care (Anc) Pada Ibu Hamil Trimester III Di Kelurahan Pojoksari Kecamatan Ambarawa Kabupaten Semarang. Jurnal Dosen Kebidanan Universitas Ngudi Waluyo Ungaran No.16 Vol.2

Raisanen, Sari. (2016). Fear Of Childbirth Predicts Postpartum Depression. http://dx.doi.org/10.1136/bmjopen-2013004047;

Rubbyana, Urifah. ( 2012). Hubungan Antara Strategi Coping dengan Kualitas Hidup pada Penderita Skizofernia Remisi Simptom. Jurnal psikologi Klinis dan Kesehatan Mental Universitas Airlangga Surabaya No.02 Vol.1

Sari, Retno. (2015). Pengaruh Konsep diri terhadap status kesehatan ibu postpartum di wilayah puskesmas napal. Jurnal Kebidanan. Dosen Tri Mandiri Sakti Bengkulu Jurusan Kebidanan No:15 Vol.2

Soep. (2009). Pengaruh Intervensi Psikoedukasi terhadap Pencegahan Postpartum Depression. Tesis Pascasarjana IImu Kesehatan Masyarakat Universitas Sumatera Utara;

Susilowati, Dewi. (2013) Depresi Postpartum dalam Menghadapi Perubahan Peran Pada lbu Nifas. Jurrnal Dosen Poltekkes Kemenkes Surakarta Jurusan Kebidanan No.15 Vol.1

Thurgood,Sara. (2009). Postpartum Depression. American Jurnal of Clinical Medicine; 2009.

World Health Organization (WHO). (2012). Prevalensi postpartum depression. Amerika: WHO

Yustisia, Imaninditya. (2013) Studi Diskriptif Tingkat Depresi Postpartum Pada Ibu Nifas. Jurnal Dosen Universitas Negeri Surakarta No.28 Vol.2

Zuama, Shofiyanti Nur. (2010). Hubungan antara self-concept dengan strategi coping pada mahasiswa. Jurnal IImu Kesehatan universitas Tadulako No.2 Vol.2 